\title{
Maintaining the unmethylated state
}

\author{
Steven S Smith
}

\begin{abstract}
Background: A remarkable correspondence exists between the cytogenetic locations of the known fragile sites and frequently reported sites of hypermethylation. The best-known features of fragile sites are sequence motifs that are prone to the spontaneous formation of a non-B DNA structure. These facts, coupled with the known enzymological specificities of DNA methyltransferase 1 (DNMT1), the ATP-dependent and actin-dependent helicases, and the ten-eleven translocation (TET) dioxygenases, suggest that these enzymes are involved in an epigenetic cycle that maintains the unmethylated state at these sites by resolving non-B structure, preventing both the sequestration of DNA methyltransferases (DNMTs) and hypermethylation in normal cells.

Presentation of the hypothesis: The innate tendency of DNA sequences present at fragile sites to form non-B DNA structures results in de novo methylation of DNA at these sites that is held in check in normal cells by the action of ATP-dependent and actin-dependent helicases coupled with the action of TET dioxygenases. This constitutes a previously unrecognized epigenetic repair cycle in which spontaneously forming non-B DNA structures formed at fragile sites are methylated by DNMTs as they are removed by the action of ATP-dependent and actin-dependent helicases, with the resulting nascent methylation rendered non-transmissible by TET dioxygenases.

Testing the hypothesis: A strong prediction of the hypothesis is that knockdown of ATP-dependent and actin-dependent helicases will result in enhanced bisulfite sensitivity and hypermethylation at non-B structures in multiple fragile sites coupled with global hypomethylation.

Implications of the hypothesis: A key implication of the hypothesis is that helicases, like the lymphoid-specific helicase and alpha thalassemia/mental retardation syndrome X-linked helicase, passively promote accurate maintenance of DNA methylation by preventing the sequestration of DNMTs at sites of unrepaired non-B DNA structure. When helicase action is blocked due to mutation or downregulation of the respective genes, DNMTs stall at unrepaired non-B structures in fragile sites after methylating them and are unable to methylate other sites in the genome, resulting in hypermethylation at non-B DNA-forming sites, along with hypomethylation elsewhere.
\end{abstract}

\section{Background}

Our recent work on the mechanism of action of 2'deoxyriboguanylurea (GuaUre-dR) [1], the primary breakdown product of 5-aza-2'-deoxycytidine (5azaC-dR) [2], coupled with work from multiple laboratories, as well as our own, on DNA methyltransferases (DNMTs) [3-8], the substrate specificity, mechanism of action and biological effects of helicases, such as the ERCC2, ATRX, HELLS and RecQ family of helicases [9-15], and the ten-eleven translocation (TET) dioxygenases [16-19], suggest that the mechanism responsible for most of the hypermethylation observed during carcinogenesis involves the breakdown of

Correspondence: ssmith@coh.org

City of Hope, 1500 East Duarte Road, Duarte, CA 91010, USA an epigenetic repair cycle that maintains the unmethylated state at and near the common fragile sites.

The classic examples of epigenetic downregulation in human cells and tissues are genes that are often silenced and hypermethylated during tumorigenesis. As demonstrated in Table 1, the vast majority of these genes reside at cytogenetic locations that define well-known fragile sites. This remarkable cytogenetic correspondence strongly suggests that hypermethylation, epigenetic downregulation and chromosomal fragility share common mechanistic features. The best-known feature of fragile sites is the presence of a sequence motif that is prone to the spontaneous formation of a non-B DNA structure. In addition to FRAXA [14], many other fragile sites have been shown to 
Table 1 Hypermethylation at known fragile sites

\begin{tabular}{|c|c|c|c|c|c|}
\hline Gene & Gene location & Fragile site & Fragile site type & Fragile site location & Methylation reference \\
\hline RUNX3 & $1 p 36$ & FRA1A & Aph, C & $1 p 36$ & [24] \\
\hline- & - & FRA1B & Aph, C & $1 p 32$ & - \\
\hline$A R H I$ & $1 \mathrm{p} 31$ & FRA1C & Aph, C & $1 \mathrm{p} 31.2$ & {$[25]$} \\
\hline PARG1 & $1 \mathrm{p} 22.1$ & FRA1D & Aph, C & $1 \mathrm{p} 22$ & [26] \\
\hline - & - & FRA1E & Aph, C & $1 \mathrm{p} 21.2$ & - \\
\hline S100A6 & $1 \mathrm{q} 21$ & FRA1F & Aph, C & $1 \mathrm{q} 21$ & {$[27]$} \\
\hline- & - & FRA1G & Aph, C & $1 \mathrm{q} 25.1$ & - \\
\hline PTGS2 & $1 q 25.2-25.3$ & FRA1G & Aph, C & $1 \mathrm{q} 25.1$ & {$[28,29]$} \\
\hline DISC1 & $1 \mathrm{q} 42.1$ & FRA1H & 5azaC-R, C & $1 q 42$ & [30] \\
\hline- & - & FRA1I & Aph, C & $1 q 44$ & - \\
\hline- & - & FRA1J & 5azaC-R, C & $1 q 12$ & - \\
\hline GLUL & $1 q 31$ & FRA1K & Aph, C & $1 q 31$ & [31] \\
\hline CLCA2 & $1 \mathrm{p} 31$ & FRA1L & Aph, C & $1 \mathrm{p} 31$ & [32] \\
\hline MIR137 & $1 p 21.3$ & FRA1M & Fol, R & $1 \mathrm{p} 21.3$ & [33] \\
\hline- & - & FRA2A & Fol, $R$ & $2 q 11.2$ & - \\
\hline BCL2L11 & $2 q 13$ & FRA2B & Fol, R & $2 q 13$ & [34] \\
\hline- & - & FRA2C & Aph, C & $2 p 24.2$ & - \\
\hline MSH6 & $2 p 16$ & FRA2D & Aph, C & $2 \mathrm{p} 16.2$ & [35] \\
\hline DOK1 & $2 p 13$ & FRA2E & Aph, C & $2 p 13$ & [36] \\
\hline RASSF1 & $3 p 21.3$ & - & - & - & [37] \\
\hline MLH1 & $3 p 21.3$ & - & - & - & [38] \\
\hline VHL & $3 p 25.3$ & - & - & - & [39] \\
\hline$\angle R P 1 B$ & $2 q 21.2$ & FRA2F & Aph, C & $2 q 21.3$ & [40] \\
\hline HOXD1 & $2 q 31.1$ & FRA2G & Aph, C & $2 q 31$ & [41] \\
\hline- & - & FRA2H & Aph, C & $2 q 32.1$ & - \\
\hline FLIP & $2 q 33-q 34$ & FRA2I & Aph, C & $2 q 33$ & [42] \\
\hline KIFTA & $2 q 37.3$ & FRA2J & Aph, C & $2 q 37.3$ & [43] \\
\hline ZEB2 & $2 q 22.3$ & FRA2K & Fol, R & $2 q 22.3$ & [44] \\
\hline$R A R \beta$ & $3 p 24.2$ & FRA3A & Aph, C & $3 p 24.2$ & [45] \\
\hline FHIT & $3 p 14.2$ & FRA3B & Aph, C & $3 p 14.2$ & {$[46]$} \\
\hline- & - & FRA3C & Aph, C & $3 q 27$ & - \\
\hline RARRES1 & $3 q 25.32$ & FRA3D & Aph, C & $3 q 25$ & [47] \\
\hline PTX3 & $3 q 25$ & FRA3D & Aph, C & $3 q 25$ & [48] \\
\hline- & - & FRA4A & Aph, C & $4 p 16.1$ & - \\
\hline PDGFRA & $4 q^{12}$ & FRA4B & BrdU, C & $4 q 12$ & [49] \\
\hline SFRP2 & $4 q 31.3$ & FRA4C & Aph, C & $4 q 31.1$ & [50] \\
\hline SLIT2 & $4 p 15.2$ & FRA4D & Aph, C & $4 p 15$ & [51] \\
\hline - & - & FRA5A & $\mathrm{BrdU}, \mathrm{C}$ & $5 p 13$ & - \\
\hline- & - & FRA5B & BrdU, C & $5 q 15$ & - \\
\hline $\mathrm{NR3C1}$ & $5 q 31.3$ & FRA5C & Aph, C & $5 q 31.1$ & [52] \\
\hline GPR150 & $5 q 15$ & FRA5D & Aph, C & $5 q 15$ & [53] \\
\hline- & - & FRA5E & Aph, C & $5 p 14$ & - \\
\hline$A P C$ & $5 q 21-22$ & FRA5F & Aph, C & $5 q 21$ & [54] \\
\hline- & - & FRA5G & Fol, R & $5 q 35$ & - \\
\hline
\end{tabular}


Table 1 Hypermethylation at known fragile sites (Continued)

\begin{tabular}{|c|c|c|c|c|c|}
\hline Gene & Gene location & Fragile site & Fragile site type & Fragile site location & Methylation reference \\
\hline SCGB3A1 & $5 q 35.3$ & FRA5G & Fol, $R$ & $5 q 35$ & {$[55,56]$} \\
\hline- & - & FRA6A & Fol, $\mathrm{R}$ & $6 p 23$ & - \\
\hline - & - & FRA6B & Aph, C & $6 \mathrm{p} 25.1$ & - \\
\hline- & - & FRA6C & Aph, C & $6 p 22.2$ & - \\
\hline - & - & FRA6C & Aph, C & $6 p 22.2$ & - \\
\hline - & - & FRA6D & $\mathrm{BrdU}, \mathrm{C}$ & $6 q 13$ & - \\
\hline ESR1 & $6 q 25.1$ & - & - & - & {$[57]$} \\
\hline- & & FRA6E & Aph, C & $6 q 26$ & - \\
\hline HACE1 & $6 q 21$ & FRA6F & Aph, C & $6 q 21$ & [58] \\
\hline- & - & FRA6G & Aph, C & $6 q 15$ & - \\
\hline- & - & FRA7A & Fol, R & $7 p 11.2$ & - \\
\hline TWIST1 & $7 p 21.2$ & - & - & - & {$[56]$} \\
\hline- & - & FRA7B & Aph, C & $7 p 22$ & \\
\hline - & - & FRA7C & Aph, C & $7 p 14.2$ & - \\
\hline IGFBP3 & 7p13-p12 & FRA7D & Aph, C & $7 p 13$ & [59] \\
\hline $\mathrm{HICl}$ & 17p13.3 & FRA7D & Aph, C & $7 p 13$ & [60] \\
\hline$A B C B 1$ & $7 q 21.12$ & FRA7E & Aph, C & $7 q 21.2$ & [61] \\
\hline TFPI2 & $7 q 22$ & FRA7F & Aph, C & $7 q 22$ & [62] \\
\hline TES & $7 q 31.2$ & FRA7G & Aph, C & $7 q 31.2$ & [63] \\
\hline CFTR & $7 q 31.2$ & FRA7G & Aph, C & $7 q 31.2$ & [64] \\
\hline- & - & FRA7H & Aph, C & $7 q 32.3$ & - \\
\hline EN2 & $7 q 36$ & FRA7I & Aph, C & $7 q 36$ & {$[65]$} \\
\hline HSPB1 & $7 q 11.23$ & FRA7J & Aph, C & $7 q 11$ & [66] \\
\hline - & - & FRA8A & Fol, R & $8 q 22.3$ & - \\
\hline- & - & FRA8B & Aph, C & $8 q 22.1$ & - \\
\hline MYC & $8 q 24.21$ & FRA8C, & Aph, C & $8 q 24.1$ & [67] \\
\hline- & - & FRA8D & Aph, C & $8 q 24.3$ & - \\
\hline MYC & $8 q 24.21$ & FRA8E & Dmy, R & $8 q 24.1$ & [67] \\
\hline CDKN2A & $9 p 21$ & FRA9A, & Fol, R & $9 p 21$ & {$[68]$} \\
\hline CDKN2B & $9 p 21$ & FRA9A, & Fol, R & $9 p 21$ & [69] \\
\hline BRINP1 & $9 q 32-q 33$ & FRA9B, & Fol, R & $9 q 32$ & [70] \\
\hline CDKN2A & $9 p 21$ & FRA9C, & BrdU, R & $9 p 21$ & {$[68]$} \\
\hline CDKN2B & $9 p 21$ & FRA9C, & BrdU, R & $9 p 21$ & [69] \\
\hline \multirow[t]{2}{*}{ DAPK1 } & $9 q 21.33$ & FRA9D & Aph, C & $9 q 22.1$ & [71] \\
\hline & & FRA9B, & Aph, C & $9 q 32$ & \\
\hline$B A R \times 1$ & $9 q 12$ & FRA9F & 5azaC-R, C & $9 q 12$ & [72] \\
\hline FRA1OAC1 & $10 q 23.33$ & FRA10A & Fol, R & 10q23.3 & [73] \\
\hline PTEN & 10q23.3 & FRA10A & Fol, R & $10 \mathrm{q} 23.3$ & [74] \\
\hline \multirow[t]{2}{*}{-} & & FRA10B & BrdU, R & $10 q 25.2$ & \\
\hline & & FRA10C & BrdU, R & $10 q 21$ & \\
\hline EGR2 & $10 q 21.1$ & FRA10D & Aph, C & $10 q 21.1$ & [75] \\
\hline TYSND1 & $10 q 22.1$ & FRA10D & Aph, C & $10 q 22.1$ & [76] \\
\hline- & - & FRA10E & Aph, C & $10 q 25.2$ & \\
\hline MGMT & $10 q 26$ & FRA10F & Aph, C & 10q26.1 & [77] \\
\hline
\end{tabular}


Table 1 Hypermethylation at known fragile sites (Continued)

\begin{tabular}{|c|c|c|c|c|c|}
\hline Gene & Gene location & Fragile site & Fragile site type & Fragile site location & Methylation reference \\
\hline RET & $10 q 11.2$ & FRA10G & Aph, C & $10 q 11.2$ & [78] \\
\hline MRPL48 & $11 q 13.4$ & FRA11A & Fol, R & $11 q 13.3$ & [79] \\
\hline AMICA1 & $11 \mathrm{q} 23.3$ & FRA11B & Fol, $R$ & $11 \mathrm{q} 23.3$ & {$[80]$} \\
\hline$C A L C B$ & 11 p15.2- & FRA11C & Aph, C & 11 p15.1 & [81] \\
\hline HRAS & $11 p 15.5$ & FRA11C, & Aph, C & 11 p15.1 & [81] \\
\hline MYOD1 & $11 p 15.4$ & FRA11C, & Aph, C & $11 p 15.1$ & {$[64]$} \\
\hline - & - & FRA11D & Aph, C & $11 p 14.2$ & \\
\hline WT1 & $11 p 13$ & FRA11E & Aph, C & $11 p 13$ & {$[82]$} \\
\hline CD44 & $11 p 13$ & FRA11E & Aph, C & $11 p 13$ & [83] \\
\hline- & - & FRA11F & Aph, C & $11 p 14.2$ & \\
\hline$P G R$ & $11 q 22-q 23$ & FRA11G & Aph, C & $11 \mathrm{q} 23.3$ & {$[84]$} \\
\hline GSTP1 & $11 q 13$ & FRA11H & Aph, C & $11 q 13$ & [85] \\
\hline CCND2 & $12 \mathrm{p} 13$ & - & - & - & {$[56]$} \\
\hline$C A L C B$ & $11 p 15.2-15.1$ & FRA11I & Aph, C & $11 p 15.1$ & [81] \\
\hline HRAS & $11 p 15.5$ & FRA111, & Aph, C & $11 p 15.1$ & {$[81]$} \\
\hline MYOD1 & $11 p 15.4$ & FRA111, & Aph, C & 11 p15.1 & {$[64]$} \\
\hline- & - & FRA12A & Fol, R & $12 q 13.1$ & \\
\hline SLC6A15 & $12 q 21.3$ & FRA12B & Aph, C & $12 q 21.3$ & {$[62]$} \\
\hline CHFR & $12 q 24.33$ & FRA12C & BrdU, R & $12 q 24.2$ & {$[86]$} \\
\hline- & - & FRA12D & Fol, $\mathrm{R}$ & $12 q 24.13$ & \\
\hline SELPLG & $12 q 24$ & FRA12E & Aph, C & $12 q 24$ & [87] \\
\hline$B R C A 2$ & $13 q 12.3$ & FRA13A & Aph, C & $13 q 13.2$ & [35] \\
\hline$R B 1$ & $13 q 14.2$ & - & - & - & {$[88]$} \\
\hline PCDH2O & $13 q 21.2$ & FRA13B & $\mathrm{BrdU}, \mathrm{C}$ & $13 q 21$ & [89] \\
\hline $\mathrm{PCDH} 2 \mathrm{O}$ & $13 q 21.2$ & FRA13C & Aph, C & $13 q 21.2$ & [89] \\
\hline ZIC2 & $13 q 32$ & FRA13D & Aph, C & $13 q 32$ & [90] \\
\hline- & - & FRA15A & Aph, C & $15 q 22$ & \\
\hline$A B C C 6$ & 16p13.1 & FRA16A & Fol, R & $16 p 13.11$ & {$[64]$} \\
\hline $\mathrm{CDH} 1$ & $16 q 22.1$ & FRA16B, & Dmy, R & $16 q 22.1$ & [91] \\
\hline $\mathrm{CDH} 1$ & $16 q 22.1$ & FRA16C & Aph, C & $16 q 22.1$ & [91] \\
\hline $\mathrm{CDH} 13$ & $16 q 23.3$ & FRA16D & Aph, C & $16 q 23.2$ & [92] \\
\hline WWOX & $16 q 23.3-q 24.1$ & FRA16D & Aph, C & $16 q 23.2$ & [93] \\
\hline HICl & 17p13.3 & - & - & - & {$[60]$} \\
\hline- & - & FRA17A & Dmy, R & $17 p 12$ & \\
\hline BRCA1 & $17 q 21.31$ & - & - & - & [94] \\
\hline soxg & $17 q 23$ & FRA17B & Aph, C & $17 q 23.1$ & [95] \\
\hline $\mathrm{CDH} 2$ & $18 q 12.1$ & FRA18A & Aph, C & $18 q 12.2$ & [72] \\
\hline SERPINB5 & $18 q 21.33$ & FRA18B & Aph, C & $18 q 21.3$ & [96] \\
\hline$B C L 2$ & $18 q 21.3$ & FRA18B & Aph, C & $18 q 21.3$ & [64] \\
\hline- & - & FRA18C & Aph, C & $18 q 22.2$ & \\
\hline - & - & FRA19A & 5azaC-R, C & $19 q 13$ & \\
\hline- & - & FRA19B & Fol, R & $19 p 13$ & \\
\hline- & - & FRA20A & Fol, R & $20 p 11.23$ & \\
\hline- & - & FRA20B & Aph, C & 20p12.2 & \\
\hline
\end{tabular}


Table 1 Hypermethylation at known fragile sites (Continued)

\begin{tabular}{|c|c|c|c|c|c|}
\hline Gene & Gene location & Fragile site & Fragile site type & Fragile site location & Methylation reference \\
\hline- & - & FRA20B & Aph, C & $20 p 12.2$ & \\
\hline FBLN1 & $22 q 13$ & FRA22A & Fol, R & $22 q 13$ & [97] \\
\hline - & $22 q 12.1$ & FRA22B & Aph, C & $22 q 12.2$ & \\
\hline$A R$ & $\mathrm{Xq12}$ & - & - & - & [98] \\
\hline FMR1 & $X q 27.3$ & FRAXA & Fol, $\mathrm{R}$ & Xq27.3 & [14] \\
\hline$v C X$ & Xp22 & FRAXB & Aph, C & Xp22.31 & [99] \\
\hline$V C X$ & Xp22 & FRAXC & Aph, C & $X q 22.1$ & [99] \\
\hline FMR1 & $\mathrm{Xq} 27.3$ & FRAXD & Aph, C & $X q 27.2$ & [100] \\
\hline FMR2 & $X q 28$ & FRAXE, & Fol, R & $\mathrm{Xq} 28$ & [101] \\
\hline FMR2 & $X q 28$ & FRAXF & Fol, R & Xq28 & [101] \\
\hline
\end{tabular}

Definitions for standard gene abbreviations are available at the HUGO Gene Nomenclature Committee (HGNC) website [102]. Aph, aphidicolin; 5azaC-R, 5-azacytidine ; BrdU, bromodeoxyuridine; C, common; Dmy, distamycin; Fol, folate; R, rare.

harbor sequences, such as the CCG triplet repeat, which form hairpins, slippage intermediates (Figure 1A) and quadruplex structures. Non-B intermediates are known to be exceptional substrates for de novo methylation by DNA methyltransferase 1 (DNMT1) $[6,7,20]$ either at its threenucleotide recognition motif (Figure 1) within the repeat if it contains CG sites or at the same motif at CG sites flanking the non-B sequence if it does not. Consequently, even fragile sites that contain AT-rich sequences with high torsional flexibility and the potential for non-B DNA structure formation are subject to methylation in regions flanking the repeat. Other fragile sites that lack CG dimers, such as the Huntington's disease CAG repeat, which can also form hairpins and slippage intermediates [7,21], appear to induce methylation at the flanking and other regions where CG dimers occur [7,22]; for a review, see Lukusa and Fryns [23].

\section{Presentation of the hypothesis}

The key components of the hypothesis, presented in Figure 1, are: 1) carcinogenesis-linked hypermethylation that occurs primarily at or near fragile sites as a result of the tendency of DNA sequences at these sites to form non-B structures; 2) methylation is applied de novo to these structures and their neighboring sequences not only by DNMT3A/3B but also by DNMT1; 3) during normal replication methylated non-B DNA structures are returned to the B form by ERCC2, ATRX, HELLS and RecQ helicases; 4) sequences that cannot be resolved by helicase action are removed by excision; 5) hydroxymethylation applied to the nascent methyl groups by the action of TET dioxygenases prevents sequences that are resolved by helicase action from undergoing maintenance methylation by DNMT1, regenerating the unmethylated state at these sites in normal cells (in this regard, it is important to recognize that resolution of these structures will result in hemimethylated DNA, and that hemimethylated DNA is the preferred substrate of TET1 dioxygenase [17]); and 6) in addition to DNA damage, carcinogenesis-linked dysfunction among the helicases results in hypermethylation at and near fragile sites, and hypomethylation elsewhere.

\section{Testing the hypothesis}

While the existing evidence for the proposed cycle is compelling, currently available experimental approaches permit several additional tests of the hypothesis. For example, transient knockdown by transfection-mediated expression of an ERCC2, ATRX, HELLS or RecQ helicase is predicted to result in a transient hypermethylation, coupled with an increase in local hydroxymethylation content at affected fragile sites. Stable knockdown is expected to result in both hypermethylation at affected fragile sites and global hypomethylation. In particular, the knockdown of the WRN helicase (REQL2) is predicted to result in hypermethylation of the FHIT gene at FRA3B [108], coupled with enhanced bisulfite sensitivity [109] of native DNA associated with the increased presence of non-B DNA structure at this site $[109,110]$. Existing studies on the effect of WRN mutations on methylation, for example, do not address early events at fragile sites, since they use cell lines that have been carried in culture or were isolated from adults bearing the WRN mutation $[111,112]$. Chromatin immunoprecipitation with antibodies to DNMT1 is expected to yield DNA that is enriched for fragile site sequences after helicase knockdown. Determining the levels of DNMT1 by immunoblotting after helicase knockdown would determine whether or not the removal of stalled DNMT1 involves proteolysis [113]. WRN knockdown coupled with DNMT1 knockdown is expected to produce enhanced bisulfite sensitivity $[109,110]$ in the absence of hypermethylation, while enhanced bisulfite sensitivity after knockdown of DNMT1 alone would provide evidence for an obligatory role of methylation in non-B structure resolution. 


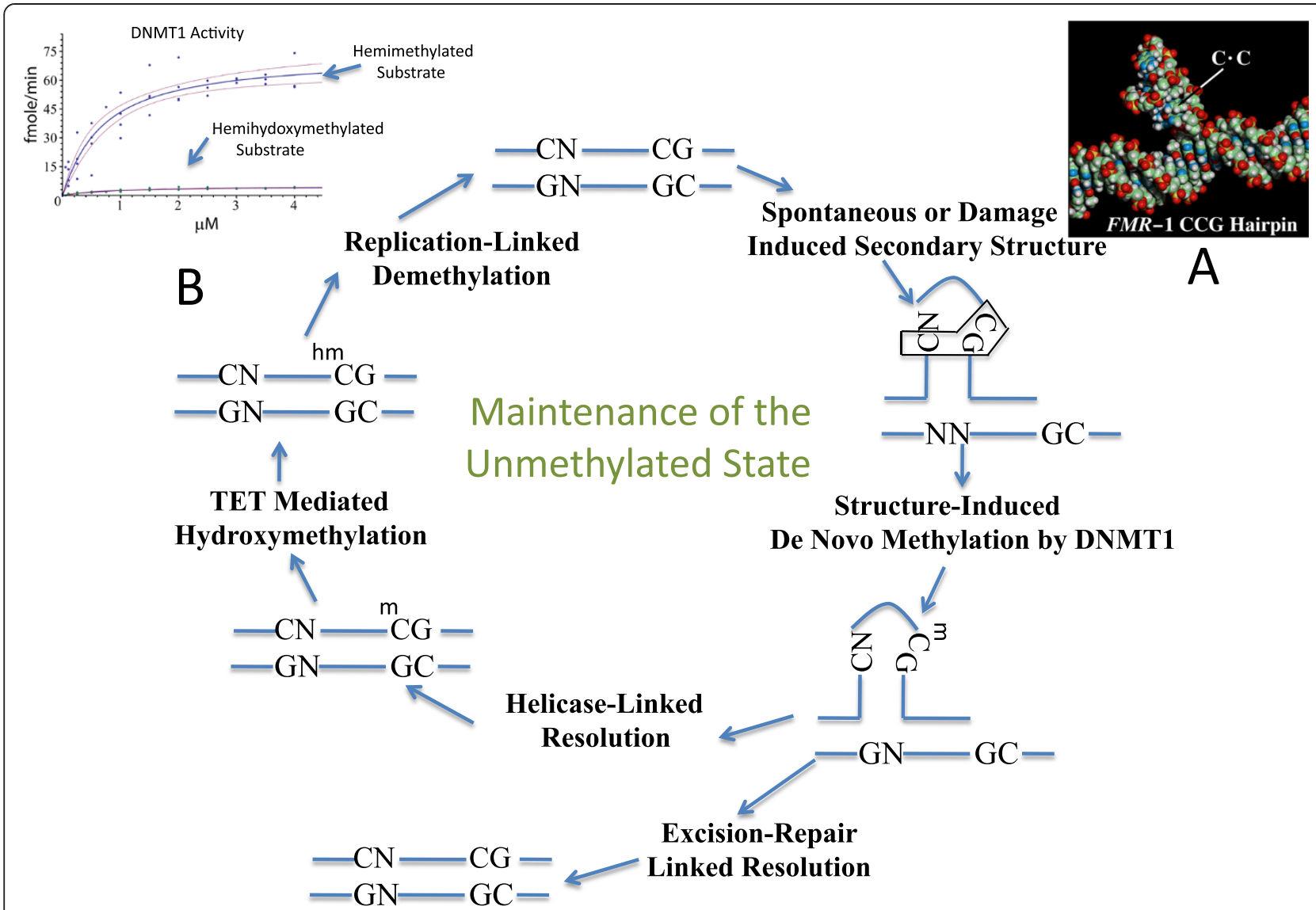

Figure 1 Key systems maintaining the active and unmethylated state of DNA at sequences with the innate potential for non-B DNA structure formation. In this enzymologically-based model, non-B DNA structure forms spontaneously or in response to replication stress or carcinogen-linked damage, inducing DNA methylation de novo [3,4,103,104]. The three-nucleotide recognition motif [4] of DNMT1 (C:G-C) is highlighted in the schematic of the non-B structure in the upper right of the figure. Helicase resolution at non-B structures produces hemimethylated DNA. Hypermethylation is prevented by the action of TET dioxygenase on its preferred hemimethylated substrate [17]. When stress overwhelms the capacity of TET dioxygenase to hydroxymethylate hemimethylated DNA in the affected region, hypermethylation will result. In this model, helicase lesions, DNMT lesions or TET dioxygenase lesions are expected to generate chromosome instability and the selective induction of fragile sites. Methylated unusual DNA structures that are not resolved by helicase action may be removed by excision repair-linked pathways where the unmethylated state is restored by DNA synthesis. (A) Molecular model of the hypermethylated C-rich strand hairpin formed at fragile site FRAXA. The model was constructed in Biograf 3.1 (Molecular Simulations Inc, San Diego, CA, USA) and rendered with the UCSF Chimera package (Resource for Biocomputing, Visualization, and Informatics, University of California, San Francisco, CA, USA). It is based on NMR data presented by Chen et al. [20]. (B) Activity of human DNA methyltransferase 1 (hDNMT1) on hemimethylated DNA and hemihydroxymethylated DNA. hDNMT1 was purified from nuclear extracts [105] prepared from cultured HeLa S3 cells. Purification and enzyme activity measurements were carried out as previously described $[106,107]$. The purified enzyme had a specific activity of $20.96 \mathrm{fmole}{ }^{3} \mathrm{HCH} / \mathrm{min} /$ mg. Duplex ODN substrates were synthesized and annealed as previously described [107]. The results confirm the findings of Hashimoto et al. [17] with cloned DNMT1.

Finally, as a test of the downstream portion of the cycle, overexpression of TET dioxygenases is expected to reduce de novo methylation at fragile sites caused by helicase knockdown, and knockdown of the dioxygenases should enhance de novo methylation at these same sites.

\section{Implications of the hypothesis}

The hypothesis is consistent with other suggestions for the genesis of hypermethylation [114,115]. Disruptions in the histone code might be expected to elicit fragile site formation, since exposure to carcinogens that damage DNA or block the histone modification processes, may also induce fragile sites. Alterations in DNA structure induced by miRNA (possibly via R-loop formation) could have similar effects at these sites. Moreover, the remarkable correspondence between sites of reported hypermethylation and fragile sites suggests that the mutational and epimutational base upon which natural selection can act during carcinogenesis is largely confined to these sites. Their tendency to adopt non-B DNA structures provides a compelling case for how they become available for natural selection. 
Each of the tenets of the hypothesis is supported by cytogenetic, DNA methylation and enzymological evidence. Enzymological and biological evidence from our laboratory suggests that DNMTs have evolved to recognize non-B DNA structures, like those associated with FRAXA in fragile X-linked mental retardation, and FRA11I/FRA11C in breast and prostate cancer $[20,107,110]$, suggesting that DNMTs play an obligate role in the suppression of non-B DNA structures $[116,117]$ along with associated repair systems. Given an obligate role for DNMTs in the suppression of non-B structure formation, the role of helicases in the process can be better understood. In general, deficiencies in helicases, such as ATRX, HELLS, BLM and WRN, have been shown to result in either global genomic demethylation [118,119], gene activation [10], or both global demethylation and gene activation. Two diametrically opposed interpretations of normal function of these helicases have been proposed. In one interpretation, they are viewed as actively promoting DNA methylation $[118,120]$. In the alternative interpretation, they are viewed as passively promoting normal DNA methylation by preventing the sequestration of DNMTs [107,117] at unresolved non-B structures [10]. The enzymological evidence supports the alternative interpretation. For example, the WRN helicase has been shown to resolve quadruplex DNA [15] and deficiency appears to result in the accumulation of non- $B$ structures [10]. The evidence suggests that the DNMTs remain bound to non- $\mathrm{B}$ DNA sequences containing mispaired cytosines [107], oxidized bases [121] or DNA containing base analogs, such as deoxyuridine (dU) [122], 5azaC-dR or GuaUre-dR [1]. It follows, that in cases of helicase deficiency, DNMT sequestration at a site of hypermethylation will result in global hypomethylation, much like the effects of 5-azacytidine (5azaC-R), 5azaC-dR and GuaUre-dR result in hypomethylation, since tightly bound DNMTs are unable to maintain normal methylation patterns. Moreover, this model (Figure 1) and the postulated obligatory role for DNMTs suggests that the cytogenetic overlap between 5azaC-R, $5 \mathrm{azaC}-\mathrm{dR}$ and GuaUre-dR-induced fragile sites FRA1J and FRA9F, and the undercondensations observed in DNMT3B mutants [123] and knockouts [124], is the result of the complete titration of DNMT3B by non-B structures that remain unresolved and unrepaired after exposure to these compounds. The selective effect on DNMT3B as opposed to DNMT1 can be attributed to its low level of expression relative to DNMT1. Estimates from purification data [107] suggest that DNMT1 levels are in the order of several thousand copies per cell. Northern blotting suggests that the abundance of DNMT3B is ten to twentyfold below that of DNMT1 at a few hundred copies per cell [125]. The DNA footprint of DNMT1 is approximately $23 \mathrm{bp}$ [126]. Thus, a single non-B structure involving even 1,000 bases of singlestranded DNA could sequester approximately $2 \%$ of the DNMT1 or $20 \%$ of the DNMT3B. Replication stress- inducing agents, such as aphidicolin or distamycin, can be expected to induce multiple non-B regions. During carcinogenesis, multiple rounds of sequential induction of fragile sites by replication stress and carcinogen action could result in global hypomethylation. Moreover, the shattering of metaphase that occurs at high concentrations of 5-azaCR contrasted with the confined induction of fragile sites at low concentration [127] is consistent with the idea that DNMT3B is knocked out at low concentration and DNMT1 at higher concentration, and that both are obligatorily involved in suppressing fragile sites. Finally, work with the TET dioxygenases [16-19] and the response of DNMTs to 5-hydroxymethylcytosine $(\mathrm{hmC})$ strongly suggest that hydroxymethylation at repaired and methylated genes in fragile sites will act to restore the unmethylated active state of these genes (Figure 1B).

\section{Abbreviations}

5azaC-dR: 5-aza-2'-deoxycytidine; 5azaC-R: 5-azacytidine; bp: base pair; $\mathrm{dU}$ : deoxyuridine; DNMT: DNA methyltransferase; DNMT1: DNA methyltransferase 1; DNMT3: DNA methyltransferase 3; GuaUre-dR: 2'-deoxyriboguanylurea; hDNMT1: human DNA methyltransferase 1; HGNC: HUGO Gene Nomenclature Committee; hmC: 5-

hydroxymethylcytosine; miRNA: microRNA; NMR: Nuclear magnetic resonance; ODN: Oligodeoxynucleotide; TET: Ten-eleven translocation.

\section{Competing interests}

The author declared that he has no competing interests.

\section{Acknowledgements}

The author thanks Katarzyna Lamparska for unpublished data on the activity of DNMT1 on hemimethylated and hemihydroxymethylated DNA.

Received: 30 May 2013 Accepted: 6 August 2013

Published: 30 September 2013

\section{References}

1. Lamparska K, Clark J, Babilonia G, Bedell V, Yip W, Smith SS: 2'-Deoxyriboguanylurea, the primary breakdown product of 5-aza-2'deoxyribocytidine, is a mutagen, an epimutagen, an inhibitor of DNA methyltransferases and an inducer of 5-azacytidine-type fragile sites. Nucleic Acids Res 2012, 40:9788-9801.

2. Rogstad DK, Herring JL, Theruvathu JA, Burdzy A, Perry CC, Neidigh JW, Sowers LC: Chemical decomposition of 5-aza-2'-deoxycytidine (Decitabine): kinetic analyses and identification of products by NMR, HPLC, and mass spectrometry. Chem Res Toxicol 2009, 22:1 194-1204.

3. Smith SS, Hardy TA, Baker DJ: Human DNA (cytosine-5)methyltransferase selectively methylates duplex DNA containing mispairs. Nucleic Acids Res 1987, 15:6899-6916.

4. Smith SS, Kan JL, Baker DJ, Kaplan BE, Dembek P: Recognition of unusual DNA structures by human DNA (cytosine-5)methyltransferase. J Mol Biol 1991, 217:39-51.

5. Smith SS, Kaplan BE, Sowers LC, Newman EM: Mechanism of human methyl-directed DNA methyltransferase and the fidelity of cytosine methylation. Proc Natl Acad Sci U S A 1992, 89:4744-4748.

6. Smith SS, Laayoun A, Lingeman RG, Baker DJ, Riley J: Hypermethylation of telomere-like foldbacks at codon 12 of the human c-Ha-ras gene and the trinucleotide repeat of the FMR-1 gene of fragile X. J Mol Biol 1994, 243:143-151.

7. Smith SS, Baker DJ: Stalling of human methyltransferase at single-strand conformers from the Huntington's locus. Biochem Biophys Res Commun 1997, 234:73-78.

8. Smith SS, Baker DJ, Jardines LA: A G4-DNA/B-DNA junction at codon 12 of c-Ha-ras is actively and asymmetrically methylated by DNA(cytosine-5) methyltransferase. Biochem Biophys Res Commun 1989, 160:1397-1402. 
9. Mohaghegh P, Karow JK, Brosh RM Jr, Bohr VA, Hickson ID: The Bloom's and Werner's syndrome proteins are DNA structure-specific helicases. Nucleic Acids Res 2001, 29:2843-2849.

10. Johnson JE, Cao K, Ryvkin P, Wang LS, Johnson FB: Altered gene expression in the Werner and Bloom syndromes is associated with sequences having G-quadruplex forming potential. Nucleic Acids Res 2010, 38:1114-1122.

11. Gibbons RJ, Picketts DJ, Villard L, Higgs DR: Mutations in a putative global transcriptional regulator cause $X$-linked mental retardation with alphathalassemia (ATR-X syndrome). Cell 1995, 80:837-845.

12. Fan L, Fuss JO, Cheng QJ, Arvai AS, Hammel M, Roberts VA, Cooper PK, Tainer JA: XPD helicase structures and activities: insights into the cancer and aging phenotypes from XPD mutations. Cell 2008, 133:789-800.

13. Myant K, Termanis A, Sundaram AY, Boe T, Li C, Merusi C, Burrage J, de Las Heras Jl, Stancheva I: LSH and G9a/GLP complex are required for developmentally programmed DNA methylation. Genome Res 2011, 21:83-94.

14. Oberlé I, Rousseau F, Heitz D, Kretz C, Devys D, Hanauer A, Boué J, Bertheas M, Mandel J: Instability of a 550-base pair DNA segment and abnormal methylation in fragile X syndrome. Science 1991, 252:1097-1102.

15. Fry $M$, Loeb LA: Human werner syndrome DNA helicase unwinds tetrahelical structures of the fragile $X$ syndrome repeat sequence $d(C G G) n$. J Biol Chem 1999, 274:12797-12802.

16. Ficz G, Branco MR, Seisenberger S, Santos F, Krueger F, Hore TA, Marques CJ, Andrews S, Reik W: Dynamic regulation of 5-hydroxymethylcytosine in mouse ES cells and during differentiation. Nature 2011, 473:398-402.

17. Hashimoto H, Liu Y, Upadhyay AK, Chang Y, Howerton SB, Vertino PM, Zhang $X$, Cheng $X$ : Recognition and potential mechanisms for replication and erasure of cytosine hydroxymethylation. Nucleic Acids Res 2012, 40:4841-4849.

18. Inoue A, Zhang Y: Replication-dependent loss of 5-hydroxymethylcytosine in mouse preimplantation embryos. Science 2011, 334:194.

19. Ito S, D'Alessio AC, Taranova OV, Hong K, Sowers LC, Zhang Y: Role of Tet proteins in $5 \mathrm{mC}$ to $5 \mathrm{hmC}$ conversion, ES-cell self-renewal and inner cell mass specification. Nature 2010, 466:1129-1133.

20. Chen X, Mariappan SV, Catasti P, Ratliff R, Moyzis RK, Laayoun A, Smith SS, Bradbury EM, Gupta G: Hairpins are formed by the single DNA strands of the fragile $X$ triplet repeats: structure and biological implications. Proc Natl Acad Sci U S A 1995, 92:5199-5203.

21. Gacy AM, Goellner G, Juranic N, Macura S, McMurray CT: Trinucleotide repeats that expand in human disease form hairpin structures in vitro. Cell 1995, 81:533-540.

22. Ng CW, Yildirim F, Yap YS, Dalin S, Matthews BJ, Velez PJ, Labadorf A, Housman DE, Fraenkel E: Extensive changes in DNA methylation are associated with expression of mutant huntingtin. Proc Natl Acad Sci USA 2013, 110:2354-2359.

23. Lukusa T, Fryns JP: Human chromosome fragility. Biochim Biophys Acta 2008, 1779:3-16

24. Jeong P, Min BD, Ha YS, Song PH, Kim IY, Ryu KH, Kim JH, Yun SJ, Kim WJ: RUNX3 methylation in normal surrounding urothelium of patients with non-muscle-invasive bladder cancer: Potential role in the prediction of tumor progression. Eur J Surg Oncol 2012, 38:1095-1100.

25. Yuan J, Luo RZ, Fujii S, Wang L, Hu W, Andreeff M, Pan Y, Kadota M, Oshimura M, Sahin AA, Issa JP, Bast RC Jr, Yu Y: Aberrant methylation and silencing of $\mathrm{ARHI}$, an imprinted tumor suppressor gene in which the function is lost in breast cancers. Cancer Res 2003, 63:4174-4180.

26. Ripperger T, von Neuhoff N, Kamphues K, Emura M, Lehmann U, Tauscher M, Schraders M, Groenen P, Skawran B, Rudolph C, Callet-Bauchu E, van Krieken JH, Schlegelberger B, Steinemann D: Promoter methylation of PARG1, a novel candidate tumor suppressor gene in mantle-cell lymphomas. Haematologica 2007, 92:460-468.

27. Lindsey JC, Lusher ME, Anderton JA, Gilbertson RJ, Ellison DW, Clifford SC: Epigenetic deregulation of multiple $\mathrm{S} 100$ gene family members by differential hypomethylation and hypermethylation events in medulloblastoma. Br J Cancer 2007, 97:267-274.

28. Toyota M, Shen L, Ohe-Toyota M, Hamilton SR, Sinicrope FA, Issa JP. Aberrant methylation of the Cyclooxygenase 2 CpG island in colorectal tumors. Cancer Res 2000, 60:4044-4048.

29. Woodson K, O'Reilly KJ, Ward DE, Walter J, Hanson J, Walk EL, Tangrea JA: CD44 and PTGS2 methylation are independent prognostic markers for biochemical recurrence among prostate cancer patients with clinically localized disease. Epigenetics 2006, 1:183-186.

30. Ghoshal K, Motiwala T, Claus R, Yan P, Kutay H, Datta J, Majumder S, Bai S, Majumder A, Huang T, Plass C, Jacob ST: HOXB13, a target of DNMT3B, is methylated at an upstream CpG island, and functions as a tumor suppressor in primary colorectal tumors. PLoS One 2010, 5:e10338.

31. Cavicchioli F, Shia A, O'Leary K, Haley V, Crook TR, Thompson AM, Lackner M, Lo NC, Schmid P: Epigenetic silencing of glutamine synthetase (Glul) defines glutamine depletion therapy. Cancer Res 2012, 72:p4-10-10. doi:10.1158/0008-5472.SABCS12-P4-06-10.

32. Li X, Cowell JK, Sossey-Alaoui K: CLCA2 tumour suppressor gene in $1 \mathrm{p} 31$ is epigenetically regulated in breast cancer. Oncogene 2004, 23:1474-1480.

33. Kozaki K, Imoto I, Mogi S, Omura K, Inazawa J: Exploration of tumorsuppressive microRNAs silenced by DNA hypermethylation in oral cancer. Cancer Res 2008, 68:2094-2105.

34. Fernandez SV, Huang Y, Snider KE, Zhou Y, Pogash TJ, Russo J: Expression and DNA methylation changes in human breast epithelial cells after bisphenol A exposure. Int J Oncol 2012, 41:369-377.

35. Moelans $C B$, Verschuur-Maes $A H$, van Diest PJ: Frequent promoter hypermethylation of BRCA2, CDH13, MSH6, PAX5, PAX6 and WT1 in ductal carcinoma in situ and invasive breast cancer. J Pathol 2011, 225:222-231.

36. Saulnier A, Vaissière T, Yue J, Siouda M, Malfroy M, Accardi R, Creveaux M, Sebastian S, Shahzad N, Gheit T, Hussain I, Torrente M, Maffini FA, Calabrese L, Chiesa F, Cuenin C, Shukla R, Fathallah I, Matos E, Daudt A, Koifman S, Wünsch-Filho V, Menezes AM, Curado MP, Zaridze D, Boffetta P, Brennan P, Tommasino M, Herceg Z, Sylla BS: Inactivation of the putative suppressor gene DOK 1 by promoter hypermethylation in primary human cancer. Int J Cancer 2012, 130:2484-2494.

37. Dammann R, Li C, Yoon JH, Chin PL, Bates S, Pfeifer GP: Epigenetic inactivation of a RAS association domain family protein from the lung tumour suppressor locus 3p21.3. Nat Genet 2000, 25:315-319.

38. Herman JG, Umar A, Polyak K, Graff JR, Ahuja N, Issa JP, Markowitz S, Willson JK, Hamilton SR, Kinzler KW, Kane MF, Kolodner RD, Vogelstein B, Kunkel TA, Baylin SB: Incidence and functional consequences of $\mathrm{hMLH} 1$ promoter hypermethylation in colorectal carcinoma. Proc Natl Acad Sci U S A 1998, 95:6870-6875.

39. Herman JG, Latif F, Weng Y, Lerman MI, Zbar B, Liu S, Samid D, Duan DS, Gnarra $J R$, Linehan WM, et al: Silencing of the VHL tumor-suppressor gene by DNA methylation in renal carcinoma. Proc Natl Acad Sci U S A 1994, 91:9700-9704.

40. Sonoda I, Imoto I, Inoue J, Shibata T, Shimada Y, Chin K, Imamura M, Amagasa T, Gray JW, Hirohashi S, Inazawa J: Frequent silencing of low density lipoprotein receptor-related protein 1B (LRP1B) expression by genetic and epigenetic mechanisms in esophageal squamous cell carcinoma. Cancer Res 2004, 64:3741-3747.

41. Faryna M, Konermann C, Aulmann S, Bermejo JL, Brugger M, Diederichs S, Rom J, Weichenhan D, Claus R, Rehli M, Schirmacher P, Sinn HP, Plass HP, Gerhauser C: Genome-wide methylation screen in low-grade breast cancer identifies novel epigenetically altered genes as potential biomarkers for tumor diagnosis. FASEB J 2012, 26:4937-4950.

42. van Noesel MM, van Bezouw S, Voûte PA, Herman JG, Pieters R, Versteeg R Clustering of hypermethylated genes in neuroblastoma. Genes Chromosomes Cancer 2003, 38:226-233.

43. Ostrow KL, Park HL, Hoque MO, Kim MS, Liu J, Argani P, Westra W, Van Criekinge W, Sidransky D: Pharmacologic unmasking of epigenetically silenced genes in breast cancer. Clin Cancer Res 2009, 15:1184-1191.

44. Walter K, Holcomb T, Januario T, Du P, Evangelista M, Kartha N, Iniguez L, Soriano R, Huw L, Stern H, Modrusan Z, Seshagiri S, Hampton GM, Amler LC, Bourgon R, Yauch RL, Shames DS: DNA methylation profiling defines clinically relevant biological subsets of non-small cell lung cancer. Clin Cancer Res 2012, 18:2360-2373.

45. Virmani AK, Rathi A, Zöchbauer-Müller S, Sacchi N, Fukuyama Y, Bryant D, Maitra A, Heda S, Fong KM, Thunnissen F, Minna JD, Gazdar AF: Promoter methylation and silencing of the retinoic acid receptor-beta gene in lung carcinomas. J Natl Cancer Inst 2000, 92:1303-1307.

46. Zöchbauer-Müller S, Fong KM, Maitra A, Lam S, Geradts J, Ashfaq R, Virman AK, Milchgrub S, Gazdar AF, Minna JD: 5' CpG island methylation of the FHIT gene is correlated with loss of gene expression in lung and breast cancer. Cancer Res 2001, 61:3581-3585.

47. Youssef EM, Chen XQ, Higuchi E, Kondo Y, Garcia-Manero G, Lotan R, Issa JP: Hypermethylation and silencing of the putative tumor suppressor Tazarotene-induced gene 1 in human cancers. Cancer Res 2004, 64:2411-2417. 
48. Wang JX, He YL, Zhu ST, Yang S, Zhang ST: Aberrant methylation of the $3 q 25$ tumor suppressor gene PTX3 in human esophageal squamous cell carcinoma. World J Gastroenterol 2011, 17:4225-4230.

49. Saito K, Sakurai S, Sano T, Sakamoto K, Asao T, Hosoya Y, Nakajima T, Kuwano $\mathrm{H}$ : Aberrant methylation status of known methylation-sensitive $\mathrm{CpG}$ islands in gastrointestinal stromal tumors without any correlation to the state of c-kit and PDGFRA gene mutations and their malignancy. Cancer Sci 2008, 99:253-259.

50. Kinoshita T, Nomoto S, Kodera Y, Koike M, Fujiwara M, Nakao A: Decreased expression and aberrant hypermethylation of the SFRP genes in human gastric cancer. Hepatogastroenterology 2011, 58:1051-1056.

51. Beggs AD, Jones A, Shepherd N, Arnaout A, Finlayson C, Abulafi AM, Morton DG, Matthews GM, Hodgson SV, Tomlinson IP: Loss of expression and promoter methylation of SLIT2 are associated with sessile serrated adenoma formation. PLoS Genet 2013, 9:e1003488.

52. Lind GE, Kleivi K, Meling Gl, Teixeira MR, Thiis-Evensen E, Rognum TO, Lothe RA: ADAMTS1, CRABP1, and NR3C1 identified as epigenetically deregulated genes in colorectal tumorigenesis. Cell Oncol 2006, 28:259-272.

53. Cai LY, Abe M, Izumi S, Imura M, Yasugi T, Ushijima T: Identification of PRTFDC1 silencing and aberrant promoter methylation of GPR150, ITGA8 and HOXD11 in ovarian cancers. Life Sci 2007, 80:1458-1465.

54. Esteller M, Sparks A, Toyota M, Sanchez-Cespedes M, Capella G, Peinado MA, Gonzalez S, Tarafa G, Sidransky D, Meltzer SJ, Baylin SB, Herman JG: Analysis of adenomatous polyposis coli promoter hypermethylation in human cancer. Cancer Res 2000, 60:4366-4371.

55. Mehrotra J, Vali M, McVeigh M, Kominsky SL, Fackler MJ, Lahti-Domenici J, Polyak K, Sacchi N, Garrett-Mayer E, Argani P, Sukumar S: Very high frequency of hypermethylated genes in breast cancer metastasis to the bone, brain, and lung. Clin Cancer Res 2004, 10:3104-3109.

56. Fackler MJ, McVeigh M, Mehrotra J, Blum MA, Lange J, Lapides A, Garrett E, Argani P, Sukumar S: Quantitative multiplex methylation-specific PCR assay for the detection of promoter hypermethylation in multiple genes in breast cancer. Cancer Res 2004, 64:4442-4452.

57. Ottaviano YL, Issa JP, Parl FF, Smith HS, Baylin SB, Davidson NE: Methylation of the estrogen receptor gene $\mathrm{CpG}$ island marks loss of estrogen receptor expression in human breast cancer cells. Cancer Res 1994, 54:2552-2555

58. Sakata M, Yokomizo K, Kitamura Y, Sakuraba K, Shirahata A, Goto T, Mizukami H, Saito M, Ishibashi K, Kigawa G, Nemoto H, Hibi K: Methylation of the HACE1 gene is frequently detected in hepatocellular carcinoma. Hepatogastroenterology 2013, 60:781-783.

59. Cortés-Sempere M, de Miguel MP, Pernía O, Rodriguez C, de Castro Carpeño J, Nistal M, Conde E, López-Ríos F, Belda-Iniesta C, Perona R, de Caceres II: IGFBP-3 methylation-derived deficiency mediates the resistance to cisplatin through the activation of the IGFIR/Akt pathway in non-small cell lung cancer. Oncogene 2013, 32:1274-1283.

60. Wales MM, Biel MA, el Deiry W, Nelkin BD, Issa JP, Cavenee WK, Kuerbitz SJ Baylin SB: p53 activates expression of HIC-1, a new candidate tumour suppressor gene on 17p13.3. Nat Med 1995, 1:570-577.

61. Bebek G, Bennett KL, Funchain P, Campbell R, Seth R, Scharpf J, Burkey B, Eng C: Microbiomic subprofiles and MDR1 promoter methylation in head and neck squamous cell carcinoma. Hum Mol Genet 2012, 21:1557-1565.

62. Kim YH, Lee HC, Kim SY, Yeom Yl, Ryu KJ, Min BH, Kim DH, Son HJ, Rhee PL, Kim JJ, Rhee JC, Kim HC, Chun HK, Grady WM, Kim YS: Epigenomic analysis of aberrantly methylated genes in colorectal cancer identifies genes commonly affected by epigenetic alterations. Ann Surg Oncol 2011, 18:2338-2347.

63. Wang LJ, Bai Y, Bao ZS, Chen Y, Yan ZH, Zhang W, Zhang QG: Hypermethylation of testis derived transcript gene promoter significantly correlates with worse outcomes in glioblastoma patients. Chin Med J (Engl) 2013, 126:2062-2066.

64. Yu J, Zhu T, Wang Z, Zhang H, Qian Z, Xu H, Gao B, Wang W, Gu L, Meng J, Wang J, Feng $X$, Li Y, Yao X, Zhu J: A novel set of DNA methylation markers in urine sediments for sensitive/specific detection of bladder cancer. Clin Cancer Res 2007, 13:7296-7304.

65. Bennett LB, Schnabel JL, Kelchen JM, Taylor KH, Guo J, Arthur GL, Papageorgio CN, Shi H, Caldwell CW: DNA hypermethylation accompanied by transcriptional repression in follicular lymphoma. Genes Chromosomes Cancer 2009, 48:828-841
66. Vasiljević N, Ahmad AS, Beesley C, Thorat MA, Fisher G, Berney DM, Møller $\mathrm{H}, \mathrm{Yu}$ Y, Lu YJ, Cuzick J, Foster CS, Lorincz AT: Association between DNA methylation of HSPB1 and death in low Gleason score prostate cancer. Prostate Cancer Prostatic Dis 2013, 16:35-40.

67. Papaggeli PC, Kortsaris AC, Matsouka PT: Aberrant methylation of c-myc and c-fos protooncogenes and p53 tumor suppressor gene in myelodysplastic syndromes and acute non-lymphocytic leukemia. J BUON 2003, 8:341-350.

68. Herman JG, Merlo A, Mao L, Lapidus RG, Issa JP, Davidson NE, Sidransky D, Baylin SB: Inactivation of the CDKN2/p16/MTS1 gene is frequently associated with aberrant DNA methylation in all common human cancers. Cancer Res 1995, 55:4525-4530.

69. Herman JG, Jen J, Merlo A, Baylin SB: Hypermethylation-associated inactivation indicates a tumor suppressor role for p15INK4B. Cancer Res 1996, 56:722-727.

70. Habuchi T, Takahashi T, Kakinuma H, Wang L, Tsuchiya N, Satoh S, Akao T, Sato K, Ogawa O, Knowles MA, Kato T: Hypermethylation at 9q32-33 tumour suppressor region is age-related in normal urothelium and an early and frequent alteration in bladder cancer. Oncogene 2001, 20:531-537.

71. Tang X, Khuri FR, Lee JJ, Kemp BL, Liu D, Hong WK, Mao L: Hypermethylation of the death-associated protein (DAP) kinase promoter and aggressiveness in stage I non-small-cell lung cancer. J Natl Cancer Inst 2000, 92:1511-1516.

72. Kober P, Bujko M, Oledzki J, Tysarowski A, Siedlecki JA: Methyl-CpG binding column-based identification of nine genes hypermethylated in colorectal cancer. Mol Carcinog 2011, 50:846-856.

73. Sarafidou T, Kahl C, Martinez-Garay I, Mangelsdorf M, Gesk S, Baker E, Kokkinaki M, Talley P, Maltby EL, French L, Harder L, Hinzmann B, Nobile C, Richkind K, Finnis M, Deloukas P, Sutherland GR, Kutsche K, Moschonas NK, Siebert R, Gécz J, European Collaborative Consortium for the Study of ADLTE: Folate-sensitive fragile site FRA10A is due to an expansion of a CGG repeat in a novel gene, FRA10AC1, encoding a nuclear protein. Genomics 2004, 84:69-81.

74. García JM, Silva J, Peña C, Garcia V, Rodríquez R, Cruz MA, Cantos B, Provencio M, España P, Bonilla F: Promoter methylation of the PTEN gene is a common molecular change in breast cancer. Genes Chromosomes Cancer 2004, 41:117-124

75. Unoki M, Nakamura Y: Methylation at CpG islands in intron 1 of EGR2 confers enhancer-like activity. FEBS Lett 2003, 554:67-72.

76. Kroeger H, Jelinek J, Estécio MR, He R, Kondo K, Chung W, Zhang L, Shen L, Kantarjian HM, Bueso-Ramos CE, Issa JP: Aberrant CpG island methylation in acute myeloid leukemia is accentuated at relapse. Blood 2008, 112:1366-1373.

77. Esteller M, Toyota M, Sanchez-Cespedes M, Capella G, Peinado MA, Watkins DN, Issa JP, Sidransky D, Baylin SB, Herman JG: Inactivation of the DNA repair gene O6-methylguanine-DNA methyltransferase by promoter hypermethylation is associated with $\mathrm{G}$ to $\mathrm{A}$ mutations in K-ras in colorectal tumorigenesis. Cancer Res 2000, 60:2368-2371.

78. Luo Y, Tsuchiya KD, II Park D, Fausel R, Kanngurn S, Welcsh P, Dzieciatkowski S, Wang J, Grady WM: RET is a potential tumor suppressor gene in colorectal cancer. Oncogene 2013, 32:2037-2047.

79. Suh I, Weng J, Fernandez-Ranvier G, Shen WT, Duh QY, Clark OH, Kebebew E: Antineoplastic effects of decitabine, an inhibitor of DNA promoter methylation, in adrenocortical carcinoma cells. Arch Surg 2010, 145:226-232.

80. Nordlund J, Milani L, Lundmark A, Lönnerholm G, Syvänen AC: DNA methylation analysis of bone marrow cells at diagnosis of acute lymphoblastic leukemia and at remission. PLoS One 2012, 7:e34513.

81. de Bustros A, Nelkin BD, Silverman A, Ehrlich G, Poiesz B, Baylin SB: The short arm of chromosome 11 is a "hot spot" for hypermethylation in human neoplasia. Proc Natl Acad Sci U S A 1988, 85:5693-5697.

82. Royer-Pokora B, Schneider S: Wilms' tumor-specific methylation pattern in $11 \mathrm{p} 13$ detected by PFGE. Genes Chromosomes Cancer 1992, 5:132-140.

83. Lou W, Krill D, Dhir R, Becich MJ, Dong JT, Frierson HF Jr, Isaacs WB, Isaacs JT, Gao AC: Methylation of the CD44 metastasis suppressor gene in human prostate cancer. Cancer Res 1999, 59:2329-2331.

84. Gaudet MM, Campan M, Figueroa JD, Yang XR, Lissowska J, Peplonska B, Brinton LA, Rimm DL, Laird PW, Garcia-Closas M, Sherman ME: DNA hypermethylation of ESR1 and PGR in breast cancer: pathologic and epidemiologic associations. Cancer Epidemiol Biomarkers Prev 2009, 18:3036-3043. 
85. Lee WH, Morton RA, Epstein Jl, Brooks JD, Campbell PA, Bova GS, Hsieh WS, Isaacs WB, Nelson WG: Cytidine methylation of regulatory sequences near the pi-class glutathione S-transferase gene accompanies human prostatic carcinogenesis. Proc Natl Acad Sci U S A 1994, 91:11733-11737.

86. Koga T, Takeshita M, ljichi K, Yano T, Maehara Y, Sueishi K: CHFR aberrant methylation involves a subset of human lung adenocarcinoma associated with poor clinical outcomes. Hum Pathol 2013, 44:1382-1390.

87. Old RW, Crea F, Puszyk W, Hultén MA: Candidate epigenetic biomarkers for non-invasive prenatal diagnosis of Down syndrome. Reprod Biomed Online 2007, 15:227-235.

88. Nakamura M, Yonekawa Y, Kleihues P, Ohgaki H: Promoter hypermethylation of the RB1 gene in glioblastomas. Lab Invest 2001, 81:77-82.

89. Imoto I, Izumi H, Yokoi S, Hosoda H, Shibata T, Hosoda F, Ohki M, Hirohashi $S$, Inazawa J: Frequent silencing of the candidate tumor suppressor $\mathrm{PCDH} 20$ by epigenetic mechanism in non-small-cell lung cancers. Cancer Res 2006, 66:4617-4626.

90. Pfister S, Schlaeger C, Mendrzyk F, Wittmann A, Benner A, Kulozik A, Scheurlen W, Radlwimmer B, Lichter P: Array-based profiling of referenceindependent methylation status (aPRIMES) identifies frequent promoter methylation and consecutive downregulation of ZIC2 in pediatric medulloblastoma. Nucleic Acids Res 2007, 35:e51.

91. Corn PG, Heath El, Heitmiller R, Fogt F, Forastiere AA, Herman JG, Wu TT: Frequent hypermethylation of the $5^{\prime} \mathrm{CpG}$ island of $\mathrm{E}$-cadherin in esophageal adenocarcinoma. Clin Cancer Res 2001, 7:2765-2769.

92. Sato M, Mori Y, Sakurada A, Fujimura S, Horii A: The H-cadherin (CDH13) gene is inactivated in human lung cancer. Hum Genet 1998, 103:96-101.

93. Hiopoulos D, Guler G, Han SY, Johnston D, Druck T, McCorkell KA, Palazzo J, McCue PA, Baffa R, Huebner K: Fragile genes as biomarkers: epigenetic control of WWOX and FHIT in lung, breast and bladder cancer. Oncogene 2005, 24:1625-1633.

94. Esteller M, Silva JM, Dominguez G, Bonilla F, Matias-Guiu X, Lerma E, Bussaglia E, Prat J, Harkes IC, Repasky EA, Gabrielson E, Schutte M, Baylin SB, Herman JG: Promoter hypermethylation and BRCA1 inactivation in sporadic breast and ovarian tumors. J Natl Cancer Inst 2000, 92:564-569.

95. Aleman A, Adrien L, Lopez-Serra L, Cordon-Cardo C, Esteller M, Belbin TJ, Sanchez-Carbayo M: Identification of DNA hypermethylation of SOX9 in association with bladder cancer progression using CpG microarrays. $\mathrm{Br} J$ Cancer 2008, 98:466-473.

96. Mardin WA, Petrov KO, Enns A, Senninger N, Haier J, Mees ST: SERPINB5 and AKAP12 - expression and promoter methylation of metastasis suppressor genes in pancreatic ductal adenocarcinoma. BMC Cancer 2010, 10:549.

97. Kanda M, Nomoto S, Okamura Y, Hayashi M, Hishida M, Fujii T, Nishikawa Y, Sugimoto $\mathrm{H}$, Takeda S, Nakao A: Promoter hypermethylation of fibulin 1 gene is associated with tumor progression in hepatocellular carcinoma. Mol Carcinog 2011, 50:571-579.

98. Jarrard DF, Kinoshita H, Shi Y, Sandefur C, Hoff D, Meisner LF, Chang C, Herman JG, Isaacs WB, Nassif N: Methylation of the androgen receptor promoter $\mathrm{CpG}$ island is associated with loss of androgen receptor expression in prostate cancer cells. Cancer Res 1998, 58:5310-5314.

99. Fukutomi S, Seki N, Koda K, Miyazaki M: Identification of methylationsilenced genes in colorectal cancer cell lines: genomic screening using oligonucleotide arrays. Scand J Gastroenterol 2007, 42:1486-1494.

100. Stöger R, Kajimura TM, Brown WT, Laird CD: Epigenetic variation illustrated by DNA methylation patterns of the fragile-X gene FMR1. Hum Mol Genet 1997, 6:1791-1801.

101. Knight SJ, Flannery AV, Hirst MC, Campbell L, Christodoulou Z, Phelps SR, Pointon J, Middleton-Price HR, Barnicoat A, Pembrey ME, Holland J, Oostra BA, Bobrow M, Davies KE: Trinucleotide repeat amplification and hypermethylation of a CpG island in FRAXE mental retardation. Cell 1993, 74:127-134.

102. HUGO Gene Nomenclature Committee (HGNC): [http://www.genenames.org] 2011.

103. Bestor T: Supercoiling-dependent sequence specificity of mammalian DNA methyltransferase. Nucleic Acids Res 1987, 15:3835-3843.

104. Smith SS: Stalling of DNA methyltransferase in chromosome stability and chromosome remodelling (Review). Int J Mol Med 1998, 1:147-156.

105. Dignam JD, Lebovitz RM, Roeder RG: Accurate transcription initiation by RNA polymerase II in a soluble extract from isolated mammalian nuclei. Nucleic Acids Res 1983, 11:1475-1489.
106. Okuwaki M, Verreault A: Maintenance DNA methylation of nucleosome core particles. J Biol Chem 2004, 279:2904-2912.

107. Kho MR, Baker DJ, Laayoun A, Smith SS: Stalling of human DNA (cytosine-5) methyltransferase at single-strand conformers from a site of dynamic mutation. J Mol Biol 1998, 275:67-79.

108. Pirzio LM, Pichierri $P$, Bignami $M$, Franchitto $A$ : Werner syndrome helicase activity is essential in maintaining fragile site stability. J Cell Biol 2008, 180:305-314.

109. Raghavan SC, Tsai A, Hsieh CL, Lieber MR: Analysis of non-B DNA structure at chromosomal sites in the mammalian genome. Methods Enzymol 2006, 409:301-316.

110. Clark J, Smith SS: Secondary structure at a hot spot for DNA methylation in DNA from human breast cancers. Cancer Genomics Proteomics 2008 5:241-251

111. Agrelo R, Cheng WH, Setien F, Ropero S, Espada J, Fraga MF, Herranz M, Paz MF, Sanchez-Cespedes M, Artiga MJ, Guerrero D, Castells A, von Kobbe C, Bohr VA, Esteller M: Epigenetic inactivation of the premature aging Werner syndrome gene in human cancer. Proc Natl Acad Sci U S A 2006, 103:8822-8827.

112. Heyn H, Moran S, Esteller M: Aberrant DNA methylation profiles in the premature aging disorders Hutchinson-Gilford Progeria and Werner syndrome. Epigenetics 2013, 8:28-33.

113. Ghoshal K, Datta J, Majumder S, Bai S, Kutay H, Motiwala T, Jacob ST: 5-Azadeoxycytidine induces selective degradation of DNA methyltransferase 1 by a proteasomal pathway that requires the KEN box, bromo-adjacent homology domain, and nuclear localization signal. Mol Cell Biol 2005, 25:4727-4741.

114. Estécio MR, Issa JP: Dissecting DNA hypermethylation in cancer. FEBS Lett 2011, 585:2078-2086.

115. Baylin SB, Herman JG: DNA hypermethylation in tumorigenesis: epigenetics joins genetics. Trends Genet 2000, 16:168-174.

116. Smith SS: DNA methylation in eukaryotic chromosome stability. Mol Carcinog 1991, 4:91-92.

117. Smith SS, Crocitto LE: DNA methylation in eukaryotic chromosome stability revisited: DNA methyltransferase in the management of DNA conformation space. Mol Carcinog 1999, 26:1-9.

118. Jeddeloh JA, Stokes TL, Richards EJ: Maintenance of genomic methylation requires a SWI2/SNF2-like protein. Nat Genet 1999, 22:94-97.

119. Gibbons RJ, McDowell TL, Raman S, O'Rourke DM, Garrick D, Ayyub H, Higgs DR: Mutations in ATRX, encoding a SWI/SNF-like protein, cause diverse changes in the pattern of DNA methylation. Nat Genet 2000, 24:368-371.

120. Bourc'his D, Bestor TH: Helicase homologues maintain cytosine methylation in plants and mammals. Bioessays 2002, 24:297-299

121. Turk PW, Laayoun A, Smith SS, Weitzman SA: DNA adduct 8-hydroxyl-2'deoxyguanosine (8-hydroxyguanine) affects function of human DNA methyltransferase. Carcinogenesis 1995, 16:1253-1255.

122. Wendel JA, Smith SS: Uracil as an alternative to 5 -fluorocytosine in addressable protein targeting. Nanotechnology 1998, 9:297-304.

123. Xu GL, Bestor TH, Bourc'his D, Hsieh CL, Tommerup N, Bugge M, Hulten M, Qu X, Russo JJ, Viegas-Péquignot E: Chromosome instability and immunodeficiency syndrome caused by mutations in a DNA methyltransferase gene. Nature 1999, 402:187-191.

124. Dodge JE, Okano M, Dick F, Tsujimoto N, Chen T, Wang S, Ueda Y, Dyson N, $\mathrm{Li}$ E: Inactivation of Dnmt3b in mouse embryonic fibroblasts results in DNA hypomethylation, chromosomal instability, and spontaneous immortalization. J Biol Chem 2005, 280:17986-17991.

125. Robertson KD, Uzvolgyi E, Liang G, Talmadge C, Sumegi J, Gonzales FA, Jones PA: The human DNA methyltransferases (DNMTs) 1, 3a and 3b: coordinate mRNA expression in normal tissues and overexpression in tumors. Nucleic Acids Res 1999, 27:2291-2298.

126. Laayoun A, Smith SS: Methylation of slipped duplexes, snapbacks and cruciforms by human DNA(cytosine-5)methyltransferase. Nucleic Acids Res 1995, 23:1584-1589.

127. Schmid M, Haaf T, Grunert D: 5-Azacytidine-induced undercondensations in human chromosomes. Hum Genet 1984, 67:257-263.

doi:10.1186/1868-7083-5-17

Cite this article as: Smith: Maintaining the unmethylated state. Clinical Epigenetics 2013 5:17. 